\title{
Academics: Analysts or Messagers of Doom
}

\author{
by Howard Adelman
}

February 1984

In 1939, refugees were a matter of worldwide concern. The emergence of hordes of refugees in Europe at the same time as countries of resettlement closed their doors was a signal of impending doom as well as an immediate humanitarian problem. One could tell the problem had reached crisis proportions because academics drifted down from their ivory towers to describe and analyze the problem. For the first time, the Annals of the American Academy of Political and Social Science directed a full issue to refugees.

In 1983, under the editorship of Gilburt D. Loescher and John A. Scanlan, the journal has repeated that heretofore unique event and published a special issue entitled, "The Global Refugee Problem: U.S. and World Response". The impetus for the first special issue was the intensifying persecution of German and Austrian Jews combined with the reluctance of resettlement countries to take them. Canada, for example, as Abella and Troper have so amply documented in their now famous book, None is Too Many, assiduously worked to keep Jews out of our country.

The crisis is again before us, only now it is worldwide. Once again academics are calling attention to refugees and noting that refugees have become a permanent, not a temporary, problem. Once again there are ethnic conflicts, local conflagrations, disputes over the legal status of refugee claimants in the face of extremely restrictive immigration policies, and well-publicized attempts to share the burden internationally which, research has subsequently revealed, were really attempts to resist the undertaking of relief operations. Was the Honolulu conference on Southeast Asian refugees in the summer of 1983 our equivalent to the Evian Conference in 1938 in which the nations ostensibly talked about resettling the refugees but in reality plotted to prevent resettlement by putting in the spigot?
"Shouldn't we look for root causes instead of providing band-aid relief?" "By helping, are we not compounding the problem by creating a pull factor which attracts refugees to flee from their own country?" So run the arguments. No one notices that these two propositions are antagonistic, one placing the prime responsibility on the source country and the other on the country of resettlement. But they are complementary in that they both undermine relief operations. For if the medicine does not really relieve the problem (and may in fact make things worse), we then have the rationale for throwing out the bandaids. And if we can document the psychological and economic difficulties of the refugees in adjusting to other host countries, doesn't this demonstrate even further that the cure may be worse than the disease?

Academic studies of root causes; the clogging up of the legal apparatuses of host countries so that they break down; failed attempts at international cooperation; and the adjustment problems of resettled refugees: these all may not only be matters of detached research, but also, magical signals adumbrating disaster.

That is why the escalation of academic work is ominous even though it is welcome. That is why I greet the Annals second ever special issue on refugees as a matter of major interest intellectually, but also as an ominous event in humanitarian terms.

\section{$\bullet \bullet$}

The first article, "Identifying the World's Refugees", by the internationally renowned authority on refugee law, Atle Grahl-Madsen, documents the crisis in legal terms. The development of new additional legal protection for refugees has come to a virtual halt in the face of a myriad of international crises and conflicts, rising xenophobic hysteria, increasing protectionism and mass flows of asylum seekers. Grahl-
Madsen reviews the development of progressive legislation since the 1950s (which provided the legal framework for refugee protection) and the recent attempt to narrow the definition of refugee as one method of 'stemming the tide'.

We can sense in country after country a tendency toward a more restrictive interpretation and application of important provisions, sometimes even a disregard for rules of international law.

(p.15)

For example, Grahl-Madsen points to Sweden, recognized internationally for its liberality and humanitarian efforts. In the new 1980 Swedish Aliens' Act, the term 'persecution' is so defined as to restrict it to acts of a serious nature aimed directly "against the foreigner's life or freedom". Under such legislation, the benefit of the doubt cannot accrue to the petitioner. There must be direct proof that persecution of the individual is of a very serious nature.

Canada, in Grahl-Madsen's survey, appears to be an exception to the trend. He points to the government of Canada, Office of the Minister of Employment and Immigration report, "The Refugee Status Determination Process: A Report of the Task Force on Immigration Practices and Procedures" (the Robinson Report), for clearly recognizing a refugee as anyone who leaves or stays away from his home country for wellfounded fears of persecution whether or not there are also economic motives for leaving.

Grahl-Madsen, after reviewing the different categories of refugees - "convention", "mandate" "B-refugees", "humanitarian refugees" or, as in Canada, "designated class immigrants" (we prefer bureaucratese) - documents the increasing use of legal instruments to stem the tide: the abrogation of visa exemption agreements between states in order to prevent an uncontrollable in-

Continued on $p .12$ 
Academics

Continued from $p .11$

flow of asylum seekers; denying asylum seekers the right to work to make refugee life as unattractive as possible; restriction of the movements of refugees (even confining them to camps); and the use of the so-called humane deterrent (that is, reducing the living conditions in camps so that others are deterred from considering flight as an alternative to fear, anguish and misery in their home country).

\section{$\bullet \bullet$}

In a subsequent article by Astri Suhrke entitled "Indochinese Refugees: The Law and Politics of First Asylum", the use of the humane deterrent in the case of the Indochinese is documented in detail.

Any Canadian would recognize the symptoms. Visa requirements are first suggested to prevent a host of manifestly unfounded claims from one or two specific countries. They are then proposed for a much broader swath of countries without putting in place complementary measures to ensure the protection of refugees. Refugees are no longer allowed work permits under the very reasonable sounding argument that there are too many unemployed Canadians. Fewer refugee claimants are released from the lock up, etc.

As the xenophobic and protectionist tendencies increase, individual countries are increasingly unwilling to stand exposed on the front line. Without broader sharing, the most progressive countries, under international and domestic pressure, are forced to retreat to more protectionist postures; refugee protection is the casualty. GrahlMadsen's innovative proposal - the internationalization of the refugee status determination procedure and the allocation of responsibility for individual refugees or refugee groups to regional eligibility commissions - is, unfortunately an idea whose time has not come.

\section{$\bullet \bullet$}

Aristide Zolberg, a professor of Political Science at the University of Chicago and an expert on Afghan refugees and regional minorities in advanced industrial countries, has written a fascinating article in which he argues that refugees are a by-product of the creation of modern nation-states. In do- ing so, he focuses on refugees who have a well-founded fear of persecution because of their membership by birth in specific groups rather than the much narrower group of refugees persecuted for their political beliefs and actions. The state, as a source of persecution, may direct the persecution or tolerate persecution by others by failing to provide adequate protection.

Zolberg asks the question, "Under what conditions do states select certain categories of population as targets for persecution, expelling them outright or creating conditions that provoke them into risky flight?" (p.20) Zolberg suggests that, in fact, refugees may be the more fortunate members of the original target group since the very conditions which make persecution likely are commonly associated with the erection of barriers against free exit. The Baha'is in Iran immediately come to mind.

The argument is straightforward. Following Hannah Arendt, Zolberg argues that the essence of the nation-state is sovereignty. And the litmus test of sovereignty is the control over the emigration, naturalization, nationality and explusion of individuals within the nation-state. If our rights are not "natural", but depend on the acts of nation-states (that is, on national guarantees, so that charters of rights must be legislated into national statutes and not simply appealed to as part of our natural order), then it is but a short step to assert that such rights are only guaranteed to nationals and for nationals. It follows, therefore, that aliens ipso facto have no rights to be represented by counsel, to be present at their hearings, etc. Further, if an individual living within the body politic is defined by that nation-state as an alien, then s/he also has no rights. In industrial societies in which machines displace the value of human labour, larger populations can be a burden rather than a benefit, and states may opt to lose citizens rather than harbour people of different views.

Zolberg thus attempts to point to the dynamics of a political situation as a source of refugee production, rather than to economics or to the sociology of inter-group conflicts and contending interests. If the foundation of the nationstate is a particular national group, ethnic minorities will suffer. If the foundation is religious, religious minorities become the victims. Refugees are simply by-products of an early stage in the foundation of nation-states, "a concomitant of the secular transformation of empires and of small self-sufficient communities or tribes into a world of national states". (p.30) In order for nations to come into being, communities must be transformed into individuals who feel they share a common national identity. If that process is accompanied by underdevelopment, then authoritarian strategies of state and nation are adopted with a corresponding persecution of certain groups within the population (i.e., ethnic minorities whose loyalty can be doubted because they straddle more than one state, trading disaporas without a homeland, and ethnic groups associated with previous governing elites).

\section{$\bullet \bullet \bullet$}

Unfortunatley, not all the articles in The Annals share Zolberg's high calibre of intellectual stimulus. Earl Huyck, a sociologist at the Centre for Population Research, who has authored numerous articles on refugees, and Leon Bouvier, Director of Demographic Research and Policy analysis for the Population Reference Bureau in Washington, have pasted together a survey entitled, "The Demography of Refugees", which from the footnote, seems to based primarily on the research of a doctoral student in demography and statistics at the University of Pennsylvania. But since Donna Shai has not been given any credit in the title, she cannot be assigned any blame.

The article begins by doing explicitly what Grahl-Madsen so clearly warns must not be done - broadening the usage of the term 'refugee' to make it meaningless by including "environmentally motivated refugees" and "economically motivated refugees". Further, as a necessary condition of being a refugee is included, "the intent of the refugee is to return to his or her homeland once conditions have returned to normal". By this definition the Baha'is resettling abroad, and the Jews who fled Nazi Germany were not refugees.

After this inauspicious beginning, a misleading introduction to the conception of refugees, we are presented with a survey of the contemporary refugee situation which the authors, as a popula- 
tion sociologist and a demographer respectively, are presumably qualified to write. Unfortunatley, all they have done is adopt, without critical analysis (but with credit), the results published in the 1982 World Refugee Survey.

Unlike the 1983 issue, the 1982 version included in its world refugee total individuals who have resettled in Canada, the U.S., Australia, etc., thus rendering an exaggerated count of ten million refugees in 1982. This type of simplistic analysis is repeated over and over again in the survey. For example, on Palestine in the Middle East, the authors state: "The creation of the state of Israel in 1948 absorbed most of Europe's remaining Jewish refugees, but from 700,000 to 900,000 Arabs, whose ancestors had lived for generations in Palestine, lost their homes. As a result of several subsequent Middle Eastern Wars, some 1.9 million Palestinians are refugees today." (pp. 46-47)

There is too much that is misleading in such a short compass to allow this to pass. First, instead of writing that Isreal absorbed 132,000 of the 200,000 Jewish refugees remaining among the one million total of refugees in liberated Europe, the authors juxtaposed resettlement of European refugees with the creation of Palestinian refugees. Nothing is said, until the next section, of the absorption of three to four times as many Jewish refugees from Arab lands. And Arab countries are not listed as refugee senders. In effect, the misleading belief that Europeans dumped their refugee problems on the Arabs is reinforced.

Second, why do the authors say the creation of a state absorbed refugees? This implies that Israel was created to absorb refugees produced by a European problem.

Third, the number of Arab refugees was more or less 700,000 , not 700,000 to 900,000 (cf. Abu Lughod's research or my article in World Refugee Survey: 1983): the larger figures include Jewish and other non-Arab Palestinian refugees. Further, the definition of refugee was much broader than even these authors provide. Many of the Arab Palestinians displaced were migrants to the area in the previous century whose ancestors had not lived for generations in Palestine. In addition, the population of Palestinian refugees grew, not primarily as a result of subsequent Middle East wars, but primarily as a result of population growth and the redefinition of Palestinian refugees to include the children born of such refugees. Finally, the 1.9 million figure is accurate only if those who were granted citizenship in other countries (primarily Jordan) and/or who settled abroad are counted in the totals.

Medieval scholars were reputedly adept at arguing over how many angels could be counted on the head of a pin. I do not intend to imitate the modern equivalent of counting the number of errors scholars can make in the short compass of two sentences.

One might suspect the authors of bias but the real source of the problem seems to be incompetence: numerical and analytical errors are caused by the authors' superficial treatment of statistics and facts. With respect to the Middle East, Palestinian perspectives are dealt with as sloppily as Jewish ones. What Middle East authority in the last few years would assert that "the Palestinian refugee issue remains at the heart of any future Middle East settlement"? (p. 47) Self-determination for Palestinians is at the heart of the Arab-Israeli problem; the Palestinian refugee issue is not. The future of the West Bank and Gaza is important; that future will certainly have some impact on the Arab-Palestinian refugee problem. David P. Forsythe, in a later article asserts, "From 1967 more or less and certainly after 1974, diplomacy at the United Nations focused on some form of Palestinian selfdetermination rather than resettlement". (p. 90)

In another instance the authors assert, "In 1981 and 1982, Canada began admitting more refugees from Latin America and particularly Chile and El Salvador". (p. 52) But the facts are these: in the Annual Report to Parliament on Immigration Levels 1983, the 1981 refugee summary indicates only 132 government-sponsored refugees were admitted in 1981 from Latin and Central America - Chile is not even mentioned. And in 1982, the Canadian focus was again on Central America, though victims of political oppression from South America were also taken in, largely from Argentina. (In recent years, some Chilean refugees have begun to return to South America.)

\section{- -}

Leon Gordenker, an expert on international organization who teaches politics at Princeton and is an Associate of the Centre for International Studies, has included an article entitled, "Refugees in Developing Countries and Transnational Organization". He traces institutionalized refugee programs, organizational networks and social service systems to deal with the crisis of huge refugee populations in the developing world linking national governmental, international governmental and non-governmental organizations in a loose association unlikely to be replaced by an integrated mode of organized effort.

$$
\bullet \bullet
$$

Ronald Scheinman authors the only article of clear advocacy (as opposed to a descriptive or analytical article). In "Refugees: Goodby to the Good Old Days" Scheinman recognizes that refugees are a fundamental threat to the soverignty of the nation-state. In this he echoes Zolberg. Scheinman argues that the combination of unmanageable numbers with the large increase of new nation-states, the use of refugee status as a tool of diplomacy by developed states, and a period of economic contraction and rising protectionism have combined to create the present crisis. The problem then is how to deal realistically with protecting one's own national interest while dealing on a humanitarian basis with international and moral obligations to refugees.

\section{$\bullet \bullet$}

Scheinman joins Grahl-Masden against the thrust of Huyck and Bouvier - in insisting on maintaining the international legal definition of a refugee. He also proposes linking resettlement efforts to development aid. The latter would assist all displaced persons and ameliorate some of the root causes of forced migration. The message is simple: keep tight one's standards of who is a refugee while extending economic aid to the wider situation which produces economic displacement. The article reiterates the theme of the proposed UN fund for durable solutions and outlines the consequences of past failures in this sphere which compounded the present problem.

Continued on p. 14 


\section{Academics}

Continued from $p .13$

In 'The Palestine Question: Dealing with a Long-Term Refugee Situation", the author David Forsythe traces the Palestinian problem as it develops in three stages from a refugee to a selfdetermination problem. He also places a lot of the responsibility for the scuttling of resettlement efforts on UNRWA's policies and, in particular, its educational program (though the primary responsibility is placed on Arab opposition to resettlement).

$$
\bullet \bullet
$$

Astri Suhrke, from the School of International Service at the American University in Washington, D.C., who is a specialist in Southeast Asian Studies, is very prophetic in her article entitled, "Indochinese Refugees: The Law and Politics of First Asylum". After tracing the political factors and defining those who fled Vietnam as refugees in the early days and the recent efforts to limit the flow of refugees from Indochina, Surhke predicts that the ASEAN countries would limit asylum further and explore alternative strategies of response, given the barriers recently erected by the western resettlement countries. (I don't believe anyone predicted that the Thai navy would, in fact, begin to participate in the drowning of refugees if media reports of such occurrences are indeed true. But whatever the truth of the reports, the western media did not respond to the alleged drownings in 1984 as they once responded to the drowning of refugees off the Malaysian coast when the boats were pushed back to sea in Spring of 1979.)

Surhke's article is pessimistic in tone. She suggests that unless there is some kind of communication and negotiation with the Communist states neighbouring the refugee reception countries, there is little likelihood that humanitarianism will continue to prosper in the face of protectionist policies.

$$
\text { - • }
$$

The editors of the special issue of the Annals authored one of the articles, "U.S. Foreign Policy, 1959-80: Impact on Refugee Flow From Cuba". They correlate American foreign policy with the three phases of mass migration of Cuban refugees to the United States since Castro assumed power. The intake of 125,000 exiles in 1961 presaged, for the U.S., the forcible removal of Castro by returnees. The airlift of 261,000 Cubans from 1965 to 1973 corresponded with the objectives of the U.S. to weaken the Cuban economy and demonstrate the ideological bankruptcy of the Castro regime. Only the 1980 Muriel boatlift failed to correspond with any U.S. foreign policy objectives. And it was this group of exiles which received a less than enthusiastic welcome. Ronald Copeland, in his article on the Cuban boatlift of 1980, documents in detail the administrative fiasco in the management of the Cuban refugee exodus of 1980 .

The Loescher-Scanlan article and the Copeland article demonstrate the inextricable connection between politics and refugee policy. Though refugees are a matter of humanitarian concern, political policies in the United States clearly have a significant impact on defining who is and who is not a refugee and the reception those refugees will receive in America. Whether Vietnamese or Cuban, the attitude to them will differ radically depending on the domestic situation within the United States and on the foreign policy goals of the American administration.

The last four articles of the issue merely verify this principle. Naomi Zucker's article on the Haitians argues that this group was denied refugee status because they fled the dictatorship of an ally, because they were poor and unskilled, and because there was a belief that their acceptance would encourage others to follow. Zucker traces the myriad of methods used to restrict the inflow of Haitian refugees - the so-called humane techniques of humane deterrence. However, the courts have repeatedly found the acts of the United States government to be contrary to the laws of that government. When the United States government began to act in international waters by interdicting boats fleeing Haiti before they could reach the territorial waters of the U.S. (and therefore went beyond the jurisdiction of American courts), this policy became effective even though it may have abused international law.

Arnold Leibowitz's article, "The Refugee Act of 1980: Problems and Congressional Concerns", which fundamentally altered in law the responsibility of the U.S. to international refugees, clearly runs counter to the policies of the administration - policies which moved in the opposite direction towards control and limitation on refugee inflows. As in Canada (though the rights for refugees to claim status in the country of asylum cannot be eliminated), the debate is conducted over the judicial process and its fairness or political bias. Leibowitz traces the parallel arguments in the U.S. If refugees are cut off from aid when they appeal for asylum, this will act as a strong disincentive for refugees to come. Thus there is a direct connection between economic administrative policy and the policy of ensuring fairness to refugees who seek asylum.

Norman Zucker, in his article on refugee resettlement in the United States, traces the increasing institutionalized role of the private sector by the private voluntary agencies in their resettlement of refugees in the United States. As Leibowitz predicted, and as Zucker documents in detail, the costs of resettlement have indeed become a political and debating issue. However, Zucker gives some background to the debate and notes that the Hungarian resettlement costs could be low because their numbers were relatively small, they had well established ethnic kin and were white Europeans with high labour force participation rates, high skills and few dependents. Finally, their arrival coincided with a period of low unemployment. Since they were also perceived as brave freedom fighters fleeing an evil Communist regime, this assisted greatly in their reception. As mentioned earlier, this was not the case for the last wave of Cuban refugees, though it was for the earlier waves. It is also not the case in the present attitudes to Indochinese refugees, but it was the prevailing attitude in 1975 and '79.

Zucker documents the current federal fragmented mismanagement of the refugee resettlement programs. They have a low economic priority. The shift of attitude against the refugees, with a survival of the fittest doctrine, suggests that refugees should not be coddled but, like anyone else, should have to struggle for their own survival. Their struggle would take place among other refugees who (unlike the Hungarians) are poorly educated, are very remote from an English or western society, are unfamiliar with our culture and often have come through severe trials and tribulations to arrive here. The result is a conflict between benefits for the economically disadvantaged Americans versus 
the needs of the refugees compounded by cultural clashes.

Zucker ends on a note of praise. "Refugees infuse vitality into their new communities. They make permanent cultural, social and economic contributions. Refugees, in the final analysis, bring short-term costs and long-term benefits to their receiving communities."

Unfortunately; as all the authors have so well documented, the mood has shifted against that perception.

Barry Stein, in the final article entitled,
'The Commitment to Refugee Resettlement", argues that although the commitment to resettlement as a durable solution has increased significantly since 1975 as a base year, present challenges to that improvement have emerged, as indicated by a sharp drop in admissions. Nevertheless, Stein takes the long view and notes that the numbers have increased overall and the populations being resettled come from economic and ethnic backgrounds that are significantly different from those of earlier waves of refugee resettlement. In the tension between the obligation and need to res- pond to refugees and the bureaucratic requirement to ensure that operations are effective and admissions to a country are properly controlled with appropriate processing of claimants, the conflict between the controllers and the bleeding hearts is the focus of the present debates on status determination and other issues in the refugee field. In Stein's eyes, though the alarm signals should be raised, the pessimists should not be allowed to take over the interpretation of the development of refugee policy. Nineteen eighty-four is not the same as 1939 .

\section{Baha'i Reports}

The Baha' $i$ Faith is an independent religion with 3-4 million adherents world-wide (20,000 in Canada), coming from all ethnic and religious backgrounds. Since the Faith began in Persia (Iran) in the mid 19th Century, it has been regarded as a heresy by the Shiite Muslim clergy who now rule the country and who are outraged by the Faith's modern teachings of equality of men and women, universal education, and the harmony of religion and science.

\section{Anti-Baha'i Campaign Continues}

January 26, 1984 (Toronto, Ontario) Last year's mass hangings in Iran of Baha'i women and the regime's official ban on the practice of the religion in that country, attracted world-wide attention. Now, early in 1984, less spectacular, but equally despicable acts of violence are occurring in the regime's unrelenting, coordinated campaign to force Baha'is to recant their religion and to convert to Islam:

- 250 more Baha'i arrested (throughout the country), including infants and young children, bringing the total of Baha'i men, women and children in Iran's jails to over 700;

- two Baha'is died shortly after being confined in prison; the details of their deaths remain unknown;

- a well-known and widely-respected Baha'i man, Mr. Bahman Dihqani, was killed by a mob in Isfahan; total number of Baha'is killed by the regime since 1978 now stands at 163 ;

- imprisoned Baha'is who had been dismissed from their jobs because of their religion are promised their freedom if they pay back all the salary paid to them since beginning their employment, some up to 30 years:

- revolutionary guards are permitted to break into Baha'i homes at any hour to terrorize the occupants and seize any and all personal belongings

Official total as of January 20, 1984 of Baha'is shot, hanged, kidnapped since the beginning of the revolution for refusal to deny their faith, is $163.10,000$ Baha'is homeless, over 700 in prison.

\section{Ban of Worship and Administrative Activities}

September 19, 1983 (Toronto, Ontario) Iranian authorities have launched a new attack on the Baha'i Faith in Iran by officially banning all its worship and administrative activities.

Baha'is may practice their beliefs as private individuals. Any communal activity, however, has now been defined as a criminal act.

Douglas Martin, General Secretary of the Baha'is of Canada, stated that the authorities' suggestion that Baha' is may "practice their faith as individuals" is meaningless in a country where 156 Baha'is, including women and youth, were judicially murdered when they refused to recant rather than accept an offer of freedom if they did so, where Iran's Baha'i children cannot attend schools if they do not deny their Baha'i beliefs, where Baha'is cannot bury their dead or even receive the bodies of their slain fathers, mothers, husbands, wives or children.

\section{SWEDISH REFUGEE POLICY}

A study group of the Swedish Ministry of Labour has published a report with a number of recommendations concerning the selection and care of refugees. Among the recommendations are the following:

1. The passages to Sweden of close relatives (of refugees) will if necessary be paid for by the National Immigration and Naturalization Board (SIV).

2. Compensation should be made available to municipalities for the cost of psychiatric, psychological and social counselling of refugees.

3. The costs of child supervision and day nurseries, family day care and leisure centres should be refunded by the National Board of Health and Welfare so as to cover the net costs incurred by the municipalities after the payment of regular state grants and parents' charges.

4. All persons entering Sweden without first obtaining the requisite permits (though that absolves those who are applying for refugee status) should if necessary be assured by public measures of their upkeep while their permanent applications are pending.

5. The study group advocates research investigatory activities on a larger scale in order to acquire knowledge concerning the effects of Swedish measures on behalf of refugees. Funds should be allocated for research in this field. 